\title{
Accelerated Degradation of Metam-Sodium in Soil and Consequences for Root-Disease Management
}

\author{
Shachaf Triky-Dotan, Miriam Austerweil, Bracha Steiner, Yitzhak Peretz-Alon, Jaacov Katan, and Abraham Gamliel
}

First, second, third, and sixth authors: Laboratory for Pest Management Research, Institute of Agricultural Engineering, ARO, The Volcani Center, P.O. Box 6, Bet Dagan 50250, Israel; Fourth author: Agricultural Committee, Maon Region Enterprises, Israel; and first and fifth authors: Department of Plant Pathology and Microbiology, The Hebrew University of Jerusalem, Faculty of Agricultural, Food and Environmental Quality Sciences, Rehovot 76100, Israel.

Accepted for publication 4 December 2008.

\begin{abstract}
Triky-Dotan, S., Austerweil, M., Steiner, B., Peretz-Alon, Y., Katan, J., and Gamliel, A. 2009. Accelerated degradation of metam-sodium in soil and consequences for root-disease management. Phytopathology 99:362368.

We studied the development of accelerated degradation (AD) of methyl isothiocyanate (MITC) following repeated applications of its parent compound, metam-sodium (MS). Laboratory studies and four sets of field experiments were conducted during 2002-04 in three commercial fields in Israel. Repeated applications of MS to the three soils in the laboratory under controlled conditions demonstrated AD of MITC in some soils. In a peanut field, MS significantly reduced the incidence of Pythium pod rot

ticillium wilt in potato but its efficacy diminished after three consecutive applications. In an additional experiment, fumigation with MS following single or double applications was more effective in reducing Verticillium wilt severity of potato compared with triple applications. Soils which did not develop AD of MITC were also recorded. Preplant MS fumigation of melon fields was effective at reducing sudden wilt following a single and two consecutive applications. Our study shows that development of AD of MITC might occur following repeated applications of MS in commercial fields. The data on MITC dissipation in soil following repeated MS applications under controlled conditions indicate the chemical's potential loss of activity under regular agricultural practices and the need for a management strategy to prevent such a development.
\end{abstract} and improved pod quality after a single application but its effectiveness was greatly reduced after two applications. In a second experiment, MS was significantly effective after a single application in controlling Ver-
Additional keywords: Monosporascus cannonballus, Pythium spp., Verticillium dahliae.
Pythium pod rot of peanut, Verticillium wilt of potato, and sudden wilt of melon are common diseases in Israel and other regions where susceptible crops are frequently grown. Pythium pod rot disease of peanut is especially associated with Pythium myriotylum. The symptoms are peg decay and severe pod rot leading to a great loss in pod yield $(16,17,22)$. Potato plants are infected by Verticillium dahliae at the early stage of crop development but disease symptoms (vascular discoloration and wilt) usually appear 75 to 80 days after planting (28). Early death of the plants is usually accompanied by a significant reduction in tuber yield $(10,28)$. Sudden wilt of melon vines is caused by Monosporascus cannonballus, which is common in hot and semiarid regions, such as the Arava Valley of southern Israel (6). The first symptoms in fall crops appear 40 to 50 days after planting and infected melon plants collapse within 4 weeks, potentially leading to the destruction of the entire crop (12).

Preplant soil fumigation with metam-sodium (MS) (sodium $N$ methyl dithiocarbamate) is used worldwide to control soilborne diseases. In Israel, MS is commonly applied by chemigation to control various pathogens (e.g., Verticillium wilt in potato and Pythium pod rot in peanut) $(9,12,22,41)$. MS is combined with solarization to control sudden wilt of melon vines (6). In moist soil, MS rapidly undergoes decomposition to its active ingredient, methyl isothiocyanate (MITC), which is distributed in the vapor and liquid phase of the soil. MITC is toxic to soilborne pests, especially fungi, some soil arthropods, ectoparasitic nematodes,

Corresponding author: A. Gamliel; E-mail address: agamliel@agri.gov.il

doi:10.1094/PHYTO-99-4-0362

(c) 2009 The American Phytopathological Society and weeds $(14,30)$. Generation and dissipation of MITC in soil follows first-order degradation kinetics and is controlled by microbial and physicochemical processes $(5,13,14,29,34,47)$.

The toxic effect of MITC on pathogens, as with other pesticides under certain conditions, depends on the dosage $(C)$ and the exposure period $(T)$, resulting in a constant $(C \times T)$ for any given pest-pathogen combination (21). In a previous study, we found a significant relationship between $\mathrm{C}_{\text {MITC }} \times \mathrm{T}$ values and mortality of Fusarium oxysporum f. sp. radicis-lycopersici and $V$. dahliae in soil under controlled laboratory conditions (7), and with the incidence of Verticillium wilt in potato (40). We also found that the rate of MITC dissipation and $\mathrm{C}_{\text {MITC }} \times \mathrm{T}$ values vary among agricultural soils under controlled conditions (40).

Accelerated degradation (AD) of a pesticide in soil occurs when its active ingredient undergoes rapid decomposition, thereby losing its efficacy against pests $(1,4,19,20,36,46)$. AD is usually associated with repeated applications. Because MS is frequently used to control soilborne pests in fields of peanut, potato, and melon, the possible development of AD of MITC in these soils should be taken into consideration. AD of MITC following repeated applications of MS has been previously reported in the Netherlands $(33,35,42)$, Australia (46), and Israel (7). Under controlled conditions, MS was found to become ineffective in controlling $V$. dahliae following repeated applications as a result of $\mathrm{AD}$ of MS in soil (7).

In 2000 and 2001, evidence of inconsistent MS efficacy in controlling Verticillium wilt and Pythium pod rot was recorded in southern Israel. Thus, the objectives of the present study were to (i) examine the possibility of the development of AD of MITC following repeated applications of MS under both controlled conditions and in peanut, potato, and melon fields; and (ii) assess 
the control of Pythium pod rot of peanut, Verticillium wilt of potato, and sudden wilt of melon under such conditions.

\section{MATERIALS AND METHODS}

Four sets of field experiments were conducted during 2002-04 in three commercial fields in the Negev and Arava Valley of southern Israel. The Negev region is characterized by intensive cropping with potato and peanut for export production and the Arava region is characterized by intensive cropping with melon for export production. The fields chosen for the study had no history of MS application during the previous 4 years. The field experiments were accompanied by laboratory studies.

Soils. Soil samples were collected from the experimental field plots to assess the rate of MITC generation and dissipation under controlled conditions, in parallel to field tests using the same soil. In the first set of tests, soil samples were collected from each field before the first MS application. These samples were then repeatedly treated with MS in the laboratory in order to asses the potential for development of AD of MS under controlled conditions (Table 1; Fig. 1). In addition, soil samples were collected from the plots at the end of each cropping season to asses the effect of repeated applications in the field on the development of AD of MS. All field soil samples were collected from the upper layer (5 to $20 \mathrm{~cm}$ deep) of soil. Five subsamples of soil (total of $20 \mathrm{~kg}$ ) were mixed into one large composite sample, air dried, and sieved through a $2-\mathrm{mm}$ screen. The soils were then stored in plastic containers at room temperature until use (up to 3 weeks after collection).

Assessment of generation and dissipation of MITC in the soils. MITC generation and dissipation curves were assayed in fumigation containers as previously described $(7,40)$. Three replicate containers, each with $1 \mathrm{~kg}$ of soil, were prepared for each treatment. $F$. oxysporum f. sp. radicis-lycopersici inoculum, consisting of chlamydospores in naturally infested soil in nylon net bags, was buried in each set of soils before MS application. The containers with the soil were vibrated for $1 \mathrm{~min}$ on a reciprocal vibrator $\left(2,000\right.$ strokes $\left.\mathrm{min}^{-1}\right)$ in order to achieve uniform soil compaction and aggregation in the containers. An aqueous solution of MS (Edigan $37 \%$ a.i.; Agan-Makktechim Chemicals, Ashdod, Israel), at a rate of $60 \mu \mathrm{l} \mathrm{g}^{-1}$ of dry soil, was incorporated into the soil in each container to achieve $80 \%$ of the waterholding capacity of the treated soil. The containers with the treated soils were incubated at $25^{\circ} \mathrm{C}$ for 7 days, during which the

TABLE 1. Effect of repeated applications of metam-sodium (MS) under controlled conditions in the laboratory, at a rate of $60 \mu \mathrm{g} \mathrm{g}^{-1}$ of soil, on methyl isothiocyanate (MITC) concentration $(\mathrm{C})$ by time $(\mathrm{T})$ product $\left(\mathrm{C}_{\mathrm{MIC}} \times \mathrm{T}\right)$ in three soils, and on mortality of Fusarium oxysporum f. sp. radicis-lycopersici (FORL) in a bioassay ${ }^{x}$

\begin{tabular}{lcccr}
\hline Site & $\begin{array}{c}\text { Field } \\
\text { experiment no. }\end{array}$ & $\begin{array}{c}\text { No. of MS } \\
\text { applications }\end{array}$ & $\begin{array}{c}\mathrm{C}_{\text {MITC }} \times \mathrm{T} \\
\left(\mu \mathrm{g} \mathrm{cm}^{-3}\right)^{\mathrm{y}}\end{array}$ & $\begin{array}{c}\text { Mortality } \\
(\%)^{\mathrm{z}}\end{array}$ \\
\hline Maslul & 1 & 1 & $19.4 \mathrm{a}$ & $48.0 \mathrm{a}$ \\
\multirow{2}{*}{ Beeri } & $2 \& 3$ & 3 & $5.6 \mathrm{~b}$ & $19.0 \mathrm{a}$ \\
& & 1 & $1.8 \mathrm{a}$ & $0.0 \mathrm{a}$ \\
En Tamar & 4 & 1 & $1.2 \mathrm{a}$ & $0.0 \mathrm{a}$ \\
& & 3 & $72.2 \mathrm{a}$ & $100.0 \mathrm{a}$ \\
& & $28.8 \mathrm{~b}$ & $96.0 \mathrm{a}$ \\
\hline
\end{tabular}

x Different letters within each column, for each location, denote significant differences between treatments $(P \leq 0.05)$.

y MITC concentration was measured periodically during the fumigation process under controlled conditions in the laboratory. A gas generation and dissipation concentration curve was drawn for each soil. $\mathrm{C}_{\mathrm{MITC}} \times \mathrm{T}$ values were calculated by integrating the area under the generation-dissipation curve for each MS application for $144 \mathrm{~h}$ of incubation (40).

${ }^{\mathrm{z}}$ Nylon net bags containing soil infested with $F$. oxysporum f. sp. radicis-lycopersici chlamydospores were buried in the soil container before MS application. The bags were retrieved after 1 week and mortality was calculated by comparison with propagule viability in nontreated soil. temporal changes in MITC concentration were determined. Thereafter, the containers were opened and aerated. The net bags with fungal resting structures were retrieved and assayed for viability. Soil containers without MS application served as nontreated controls; these were prepared identically and incubated under the same conditions. MS applications were repeated three times for the relevant containers using the procedure described above at 14-day intervals. MITC concentration in the container headspace was assayed by solid-phase microextraction (SPME) and gas chromatography (GC) as previously described $(3,7)$. The lower detection limit of MITC using this method is $0.65 \mathrm{ng} \mathrm{cm}^{-3}$. The $\mathrm{C} \times \mathrm{T}$ product of MITC (expressed as micrograms per hour per cubic centimeter) was calculated as the area under the MITC concentration curve over time $(7,8,40)$. The integration was calculated numerically according to the trapezoidal rule (45).

Viability assays. The survival of $F$. oxysporum f. sp. radicislycopersici propagules following MS treatment was assessed by soil-dilution-plating technique (8). Each of three 2.5-g soil subsamples from each replicate was added to $22.5 \mathrm{ml}$ of sterile water agar $(0.1 \% \mathrm{wt} / \mathrm{vol})$ containing $\mathrm{MgSO}_{4} \cdot 7 \mathrm{H}_{2} \mathrm{O}(0.1 \% \mathrm{wt} / \mathrm{vol})$. The samples were shaken for 1 min with a bag mixer (BagMixer 400; Interscience, St. Nom-La-Breteche, France) at 8 strokes/s, then serially diluted with the same solution. Aliquots of $0.2 \mathrm{ml}$ from each dilution were spread onto the agar surface of each of four petri dishes that contained a modified peptone-pentachloronitrobenzene selective agar medium (11). The plates were incubated in the dark at $28^{\circ} \mathrm{C}$ for 4 to 6 days. Randomly selected colonies of $F$. oxysporum isolates that originated from the soil were tested for pathogenicity on tomato transplants to verify their identity as $F$. oxysporum f. sp. radicis-lycopersici (8). The results are expressed as CFU per gram of soil that had been dried at $105^{\circ} \mathrm{C}$ for $48 \mathrm{~h}$. The percent mortality was calculated by comparison with the population in the nontreated containers. In previous laboratory experiments, we found that $F$. oxysporum f. sp. radicis-lycopersici is a reliable bioassay organism for testing MS application $(7,40)$. Viability of Pythium spp. was tested by plating $0.5 \mathrm{~g}$ of soil in two petri dishes that contained sucrose-asparagine agar medium (15 spikes/dish) (31). Plates were incubated in the dark at $28^{\circ} \mathrm{C}$ for 2 to 4 days. The results are expressed as CFU per gram of soil that had been dried at $105^{\circ} \mathrm{C}$ for $48 \mathrm{~h}$. Percent mortality was calculated by comparison with the population in the nontreated soil.

Experimental setup of field trials. Experiment 1 (peanut). The first field trial was conducted in 2002 and 2003 at Maslul in the southwest desert in Israel. The soil in the field was sandyloam (clay, silt, and sand: 9, 21, and 70\%, respectively; organic matter, $1.0 \mathrm{~g} \mathrm{~kg}^{-1}$; $\mathrm{pH}$ determined in $1: 1$ [wt/wt] water extract 8.1 ;
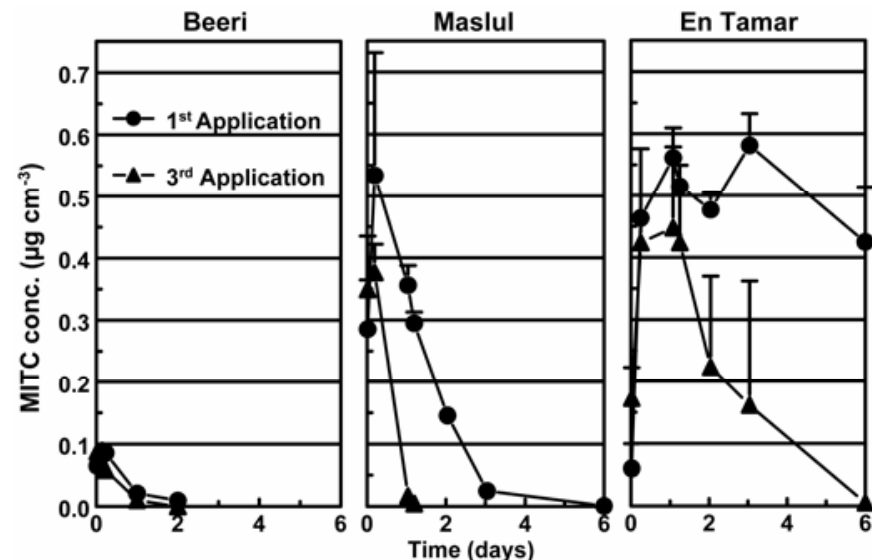

Fig. 1. Generation and dissipation of methyl isothiocyanate (MITC) in Beeri (experiments 2 and 3), Maslul (experiment 1), and En Tamar (experiment 4) soils, after single or triple applications of metam-sodium (MS) $\left(60 \mu \mathrm{g} \mathrm{g}^{-1}\right.$ soil) under controlled conditions in the laboratory. Vertical bars indicate \pm standard deviation. 
field capacity, measured at $-0.033 \mathrm{MPa}$ external pressure, of $11 \%$ ). The experimental plot was split into two: one-half was treated with MS and cropped consecutively in 2002 and 2003 in the same plots in order to generate a history of two MS applications and assess disease and pathogen control following repeated applications of MS. For comparison, the other half of the field was left fallow during 2002 and was fumigated with MS and cropped only in 2003 (the following year). Soil samples were collected from the fields before MS application and were tested for MITC degradation under controlled conditions as described above. MS was applied in the field through the sprinkler irrigation system (300 liter ha ${ }^{-1}$ at a water volume of $400 \mathrm{~m}^{3} \mathrm{ha}^{-1}$ ) in the middle of March each year. Nontreated plots served as controls and were irrigated with the same volume of water. The treatments were arranged in a randomized complete block design with five replications per treatment. Each plot was $24 \mathrm{~m}$ long and contained six beds, with three rows of plants per bed. The plots were prepared, cultivated, and treated according to the recommendations of the extension service in that region. Peanut seed (Arachis hypogaea L. cv. Hanoch) were planted at a depth of $5 \mathrm{~cm}$ by a commercial planter in the middle of April each year. Eighty days after planting, vines were periodically uprooted from each plot (eight plants per plot) and disease incidence and severity on the pods were assessed. The crop was harvested in mid-September. Pod yield was weighed and graded according to standard marketable size and quality.

Experiment 2 (potato). The second field experiment was conducted at Beeri in the southwest of Israel. The field consisted of a loam soil (clay, silt, and sand: 15, 35, and 50\%, respectively; organic matter $0.7 \mathrm{~g} \mathrm{~kg}^{-1} ; \mathrm{pH}$ determined in $1: 1$ [wt/wt] water extract 8.2 ; field capacity, measured at $-0.033 \mathrm{MPa}$ external pressure, of $15 \%$ ). The field had a history of three potato croppings in the prior 10 years and was heavily infested with $V$. dahliae. The experiment included three consecutive MS fumigations followed by three consecutive potato croppings in 2002-04; the fumigation treatments were carried out in the same plots every year. The effect of repeated applications on disease control and yield were evaluated in the same plots during the three consecutive years of cropping.

Experiment 3 (potato). The third experiment was established in the field at Beeri next to the site of experiment 2. The experimental plot was split into three subplots in order to generate three sequences of MS application during 2002-04. Each subplot was fumigated and cropped with potato as described below. In 2004, the whole field, including the three subplots, was uniformly fumigated by MS and cropped with potato. The first subplot was fumigated repeatedly (three times) in 2002, 2003, and 2004, followed by a potato crop in each year. The second subplot was cropped with wheat in 2002 and was fumigated and cropped repeatedly in 2003 and 2004. The third subplot was cropped with wheat in 2002 and 2003 and was fumigated and cropped only in 2004. Disease and yield were analyzed for the three histories of fumigation in 2004.

MS application and disease assessment in experiments 2 and 3 (potato). Treatments within each experiment and subplot (experiment 3) were arranged in a randomized complete block design with four replications per treatment. MS was applied through the sprinkler irrigation system (600 liter $\mathrm{ha}^{-1}$ at a water volume of $400 \mathrm{~m}^{3} \mathrm{ha}^{-1}$ ) at the end of August each year. Nontreated plots served as controls and were irrigated with the same volume of only water. Each plot consisted of 18 beds (bed width, $96 \mathrm{~cm}$, and length, $36 \mathrm{~m}$ ). The central beds were used for data collection. Potato (Solanum tuberosum L. cv. Marabel) (Hevel Maon Seeds, Israel) was planted in the middle of October each year. The seed tubers were planted at a depth of $15 \mathrm{~cm}$ with a commercial planter, one row per bed. The fields were sprinkle irrigated and farmed according to the recommendations for commercial potato production in the region. Potato stems with leaves were periodi- cally sampled from each plot (50 stems per plot) to assess Verticillium disease severity. The stems were rated for vascular discoloration and wilt severity on a scale of 0 to 3 , in which $0=$ no wilt or vascular system discoloration and $3=$ wilted plants covered with microsclerotia on the stem. Stem colonization by $V$. dahliae was confirmed by placing pieces of infected stems on a Verticillium-selective agar medium (2) and incubating the plates for 21 days at $18^{\circ} \mathrm{C}$. The potato foliage was desiccated after 120 days of growth and the tubers were left in the soil for an additional 3 weeks to allow the skin to mature. The tubers were manually harvested from $6 \mathrm{~m}$ of two adjacent beds at the center of each plot and were counted and graded according to standard marketable size.

Experiment 4 (melon). The fourth field experiment was conducted at Zohar experimental station in En Tamar in the northern Arava Valley. The field is made up of sandy soil (clay, silt, and sand: 4, 7, and 89\%, respectively; organic matter, $1.4 \mathrm{~g} \mathrm{~kg}^{-1} ; \mathrm{pH}$ determined in $1: 1$ [wt/wt] water extract 8.1 ; field capacity, measured at $-0.033 \mathrm{MPa}$ external pressure, of $8 \%$ ). This field had a long history of melon cropping and was heavily infested with M. cannonballus. The experimental plot was split into two. Onehalf was treated and cropped with melon repeatedly during 2002 and 2003, and MS treatment was applied in the same plots every year, in order to generate a history of two MS applications and to assess disease and pathogen control following repeated applications of MS. For comparison, the other half of the field was left fallow during 2002, and was fumigated with MS and cropped with melon only in 2003. The fumigant MS was applied on raised beds by drip lines (three lines per bed, $30-\mathrm{cm}$ spacing between lines) and the beds were then covered with polyethylene sheets (VIF, $0.03 \mathrm{~mm}$ thick; Ginegar Plastic Products Ltd., Kibbutz Ginegar, Israel) at the beginning of September each year. MS was applied at rates of 300 and 600 liter ha $^{-1}$ at a water volume of $300 \mathrm{~m}^{3} \mathrm{ha}^{-1}$. Plastic films were laid with a mechanized tarp layer (Technohak, Israel) and were left on the fumigated plots for 2 weeks, at which time they were perforated for planting. The plastic mulch was left on the soil during crop growth and production. Nontreated plots were mulched and irrigated with the same volume of water. The treatments were arranged in a randomized complete block design with five replications per treatment. The plots were prepared, cultivated, and treated according to recommendations of the extension service in that region. Each plot consisted of a 10-m-long bed (width, $1.8 \mathrm{~m}$ ) with one row of melon transplants (Cucumis melo cv. Arava; Hazera, Israel), which were planted in mid-October each year. Beginning 40 days after planting, diseased plants were counted periodically during crop growth. Melon fruit were manually harvested from the $10-\mathrm{m}$ long bed (total area of $18 \mathrm{~m}^{2}$ ). Fruit were weighed and graded according to standard marketable size.

Statistical analyses. All laboratory and controlled-system experiments were carried out at least twice. Data, taken as percentages, were arcsine-transformed before analysis. Nonparametric variables such as disease index were analyzed using the rank procedure followed by analysis of variance. Separate analyses of each experiment showed homogeneous variances of the experimental error between repeats. The effects of treatment and year in field experiments 2 and 4 were tested by two-way analysis of variance. When cross effect was significant, we compared among treatments in each year and among years for each treatment. In experiments 1 and 3, the effects of treatment were tested separately for each field section. All treatment means were compared for significant differences either by Tukey's protected test or $t$ test as indicated in each experiment. Differences in disease control under field conditions were analyzed by comparing area under the disease progress curve (AUDPC) of the relevant period (days) for each treatment. All analyses were performed with SAS software (release 8.01 for PC; SAS Institute, Cary, NC) at $P \leq 0.05$. 


\section{RESULTS}

Repeated applications of MS in the laboratory under controlled conditions. Repeated applications of MS to the three tested soils in the laboratory under controlled conditions yielded different trends with respect to MITC generation and dissipation curves (Fig. 1). Rapid dissipation of MITC was observed in the Beeri soil following both single and triple MS applications; within $48 \mathrm{~h}$, MITC was undetectable. The very rapid dissipation of MITC in this soil was also found in a previous study (40). Repeated MS applications to the Maslul soil resulted in AD of MITC. The rate of MITC dissipation in the soil from En Tamar was the slowest after the first application, with high MITC concentrations being detected even after 6 days. MITC dissipation in En Tamar soil was enhanced following triple application of MS, although the amount of MITC remaining after three applications was still high. This pattern of MITC generation and dissipation-namely, a rise and subsequent decline in its amounthas also been reported previously (40). The rate of MITC dissipation was also reflected by the $\mathrm{C}_{\text {MITC }} \times \mathrm{T}$ values and by the mortality of $F$. oxysporum $\mathrm{f}$. sp. radicis-lycopersici as a bioassay organism. $\mathrm{C}_{\mathrm{MITC}} \times \mathrm{T}$ values in Maslul and En Tamar soils were
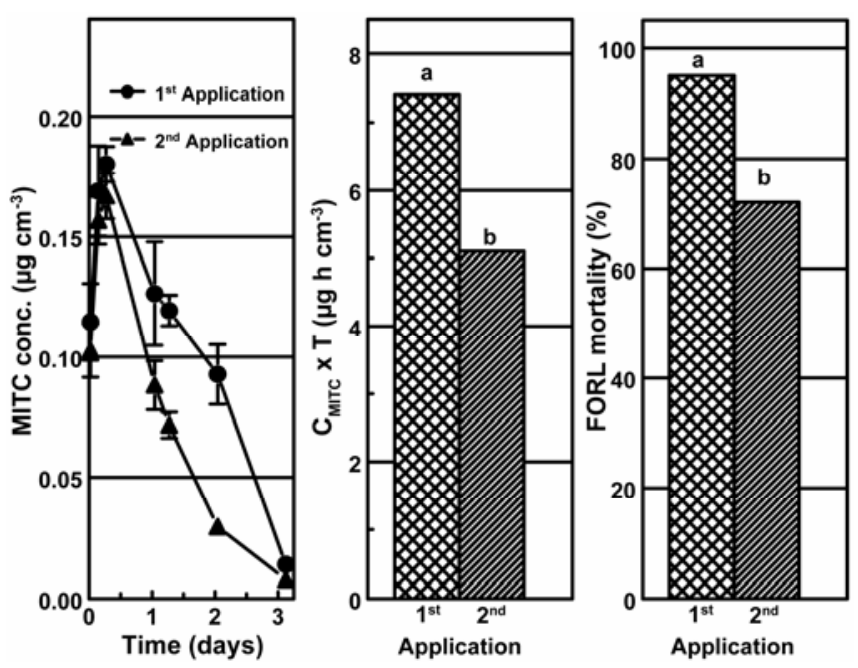

Fig. 2. Effect of repeated applications of metam-sodium (MS) in the field (experiment 1) on generation and dissipation of methyl isothiocyanate (MITC), MITC concentration (C) by time (T) products $\left(\mathrm{C}_{\mathrm{MITC}} \times \mathrm{T}\right)$, and mortality of Fusarium oxysporum f. sp. radicis-lycopersici (FORL). Values of $\mathrm{C}_{\mathrm{MITC}} \times \mathrm{T}$ were calculated from the area under the generation-dissipation curve for each MS application. Mortality of FORL was assessed after each MS application by comparing viability of the FORL population with that in nontreated soil. In each figure, different letters denote significant differences among treatments $(P \leq 0.05)$. Vertical bars indicate \pm standard deviation. significantly reduced following repeated MS applications compared with the corresponding single MS application (Table 1). $\mathrm{C}_{\text {MITC }} \times \mathrm{T}$ values were in accordance with $F$. oxysporum $\mathrm{f}$. $\mathrm{sp}$. radicis-lycopersici mortality. $\mathrm{C}_{\mathrm{MITC}} \times \mathrm{T}$ values and $F$. oxysporum f. sp. radicis-lycopersici mortality in the Beeri soil were low after both single and triple applications of MS. In contrast, $\mathrm{C}_{\text {MITC }} \times \mathrm{T}$ values and $F$. oxysporum f. sp. radicis-lycopersici mortality in En Tamar soil were high, even after three applications of MS, indicating that the AD of MITC found in this soil was not critical for pathogen control.

Repeated applications of MS in the field. Soil samples were taken from Maslul (experiment 1) plots with different histories of MS application in 2003. Thus, there were two soil histories: one soil that was treated in 2002 and 2003 and the other that was only treated once, in 2003. The soil samples were treated with MS in the laboratory and the rate of MITC dissipation was recorded. MITC dissipated within 3 days (Fig. 2). Application of MS to the soil with a history of MS application exhibited faster dissipation of MITC: the $\mathrm{C}_{\text {MITC }} \times \mathrm{T}$ value was reduced by $31 \%$ following two repeated applications of MS compared with the value obtained following a single application. The enhanced dissipation of MITC was also reflected in the mortality of $F$. oxysporum $\mathrm{f}$. sp. radicislycopersici, which was significantly reduced from $95 \%$ following a single application of MS to $72 \%$ after repeated applications (Fig. 2).

Effect of repeated MS applications in the field on pathogen and disease control and on pod yield in peanut fields: experiment 1. The fumigant MS was applied in the field either once or twice during two consecutive seasons. Viability of Pythium spp. (in soil samples collected from the field) was tested in the laboratory 3 weeks after application. MS effectively reduced the Pythium spp. population following its first application by $64 \%$ compared with $41 \%$ after the second application (Table 2). The population of Pythium spp. in the nontreated plots increased at the second crop, indicating the build-up of population of pathogen as a result of continues cropping.

An evaluation of Pythium pod rot disease was initiated 80 days after planting (Fig. 3). Pod rot incidence increased gradually during the crop season until harvest. MS significantly reduced its incidence (by 85\%) in the plots treated with a single application. In contrast, when MS was applied twice, only a nonsignificant, $14 \%$ reduction of pod rot was obtained, indicating a loss of efficacy (Fig. 3; Table 2). The same trend of decreased effectiveness of MS following repeated applications was observed for the AUDPC values (Fig. 3). The control of pod rot by MS following its first application did not result in increased total yield compared with the nontreated control. However, MS did affect pod size and quality: $77.0 \%$ of the pod yield was graded as export quality following a single MS application, whereas only $46.9 \%$ was graded as such following the repeated MS treatment (Table 2 ). The total peanut yield in the first crop was significantly higher

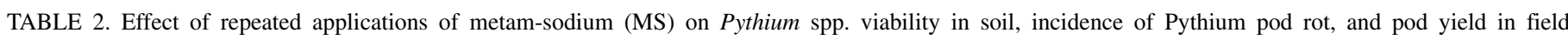
experiment $1(2002-03)^{\mathrm{u}}$

\begin{tabular}{|c|c|c|c|c|c|c|c|}
\hline \multirow[b]{2}{*}{ Treatment $^{\mathrm{v}}$} & \multirow[b]{2}{*}{ Field $^{\mathrm{w}}$} & \multirow[b]{2}{*}{ Pythium sp. $\left(\mathrm{CFU} \mathrm{g} \text { soil }^{-1}\right)^{\mathrm{x}}$} & \multirow[b]{2}{*}{$\operatorname{Rot}(\%)^{\mathrm{y}}$} & \multirow{2}{*}{$\begin{array}{c}\text { Yield }\left(\mathrm{g} \mathrm{m}^{-2}\right) \\
\text { Total pod }\end{array}$} & \multicolumn{3}{|c|}{ Yield ( $\%$ of total yield) } \\
\hline & & & & & Diseased pods ${ }^{\mathrm{z}}$ & Local market & Export \\
\hline Nontreated $(0)$ & I & $27.3 \mathrm{a}$ & $41.6 \mathrm{a}$ & $497.5 \mathrm{a}$ & $39.0 \mathrm{a}$ & $12.1 \mathrm{a}$ & $49.0 \mathrm{~b}$ \\
\hline MS (1 appl.) & I & $9.7 \mathrm{~b}$ & $6.2 \mathrm{~b}$ & $526.3 \mathrm{a}$ & $5.6 \mathrm{~b}$ & $17.4 \mathrm{a}$ & $77.0 \mathrm{a}$ \\
\hline Nontreated (0) & II & $40.0 \mathrm{a}$ & $41.4 \mathrm{a}$ & $327.5 \mathrm{a}$ & $63.5 \mathrm{a}$ & $9.8 \mathrm{a}$ & $26.8 \mathrm{a}$ \\
\hline MS (2 appl.) & II & $23.7 \mathrm{~b}$ & $35.7 \mathrm{a}$ & $397.5 \mathrm{a}$ & $38.7 \mathrm{a}$ & $14.4 \mathrm{a}$ & $46.9 \mathrm{a}$ \\
\hline
\end{tabular}

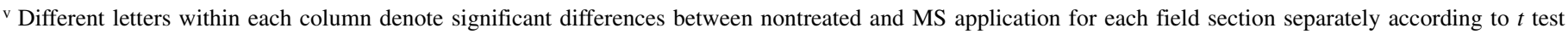
$(P \leq 0.05)$.

$\checkmark$ Number of MS applications shown in parentheses.

${ }^{w}$ Field section I: MS was applied only once in 2003; field section II: MS was applied twice in 2002 and 2003. All values refer to the 2003 crop.

x Viability of Pythium in soil was assessed 3 weeks after soil disinfestation.

y Incidence of Pythium pod rot assessed 150 days after planting. These values refer to the last sample from Figure 3.

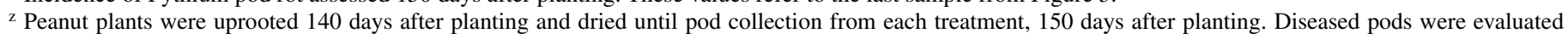
for net blotch and Pythium and Fusarium pod rots. 
than in the second crop, indicating the build-up of adverse factors for peanut cropping following monoculture of this plant.

Effect of repeated MS applications in the field on Verticillium wilt disease and on potato tuber yield: experiment 2 . Following a single application in 2002, MS was significantly effective in controlling Verticillium wilt in potato: the reduction in disease incidence and severity of the disease in potato stems was 67 and $73 \%$, respectively (Table 3). The efficacy of MS in controlling Verticillium wilt diminished after three consecutive applications, with reduction in disease incidence and severity falling to 8 and $30 \%$, respectively. Disease incidence significantly increased in the nontreated plots in 2003 and 2004 compared with 2002, apparently due to an increase in inoculum density following repeated potato cropping. The yield of potato tubers was increased by $36 \%$ following the first MS application compared with

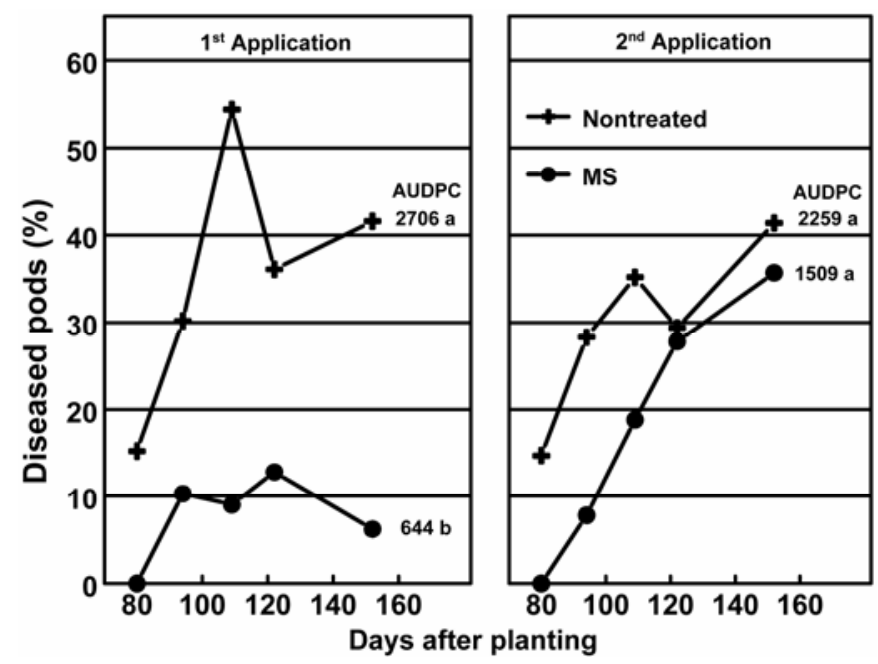

Fig. 3. Effect of repeated applications of metam-sodium (MS) on incidence of Pythium pod rot and on the area under the disease progress curve (AUDPC) (experiment 1). Starting from 80 days after planting, plants from each plot (eight plants per plot) were periodically uprooted, and disease incidence and severity of the pods was assessed. Different letters within each figure denote significant differences between treatments $(P \leq 0.05)$.

TABLE 3. Effect of repeated applications of metam-sodium (MS) on incidence and severity of Verticillium wilt and on tuber yield in potato (experiment 2) $)^{\mathrm{w}}$

\begin{tabular}{lccc}
\hline Year, treatment & $\begin{array}{c}\text { Disease } \\
\text { incidence }(\%)\end{array}$ & $\begin{array}{c}\text { Disease severity } \\
(\text { scale 0 to 3) })^{\mathrm{y}}\end{array}$ & $\begin{array}{c}\text { Total yield } \\
\left(\mathrm{kg} \mathrm{m}^{-2}\right)^{\mathrm{z}}\end{array}$ \\
\hline 2002 & & & \\
Nontreated (0) & $76.25 \mathrm{Ab}$ & $0.96 \mathrm{Ac}$ & 2.65 \\
MS (1 appl.) & $25.00 \mathrm{Bb}$ & $0.26 \mathrm{Bb}$ & 3.61 \\
2003 & & & \\
Nontreated (0) & $100.00 \mathrm{Aa}$ & $3.00 \mathrm{Aa}$ & 2.27 \\
MS (2 appl.) & $81.97 \mathrm{Ba}$ & $1.19 \mathrm{Ba}$ & 2.91 \\
2004 & & & 2.11 \\
Nontreated (0) & $98.20 \mathrm{Aa}$ & $2.02 \mathrm{Ab}$ & 2.76 \\
MS (3 appl.) & $90.65 \mathrm{Aa}$ & $1.41 \mathrm{Aa}$ & \\
\hline
\end{tabular}

${ }^{w}$ Uppercase letters denote differences among treatments within each year; lowercase letters denote differences among years for each treatment according to Tukey's multiple range test. Statistical analysis of disease incidence and severity values shows a significant interaction $(F=8.51, P \leq 0.005$ and $F=16.99, P \leq 0.0003$, respectively) among the main effects. Statistical analysis of the main effects of potato yield shows a significant difference of treatment $(F=18.4, P \leq 0.0008)$ and year $(F=6.4, P \leq 0.0106)$. Mean significant difference of main effects $(P<0.05)$ : treatment $=0.37$ and year $=$ 0.56 .

x Number of MS applications shown in parentheses.

y Disease severity was assessed by collecting stems of potato from each treatment. Stems were rated for wilt and discoloration on a scale of 0 to 3 , where $0=$ no disease symptoms and $3=$ dead plant with microsclerotia on the stem.

${ }^{\mathrm{z}}$ Potato tubers were collected and weighed 130 days after planting. the nonfumiganted control. Repeated applications of MS resulted in reduced yields in both nonfumiganted and fumigated treatments.

Experiment 3. In the second set of experiments at the Beeri site, a potato crop was planted in 2004 in three subplots, with single, double, and triple applications of MS, in order to compare these three histories of MS application in crops grown in the same year. First symptoms of the disease appeared in the nontreated plots 60 days after planting. Fumigation with MS following single or double MS applications resulted in a partial reduction in disease incidence (by 38 and 45\%, respectively) compared with only $8 \%$ after triple application, although no significant differences were observed (Table 4). A similar trend with respect to reduction in disease severity was observed after two and three MS applications. The reduction in disease severity after single or triple application was 63 and $30 \%$, respectively. There was no clear trend for yield increase by fumigation, or any significant correlation between disease control and yield increase.

Effect of repeated MS applications in the field on sudden wilt disease of melon and yield: experiment 4. MS was applied in the field, at two rates, either once or twice during two consecutive years. F. oxysporum f. sp. radicis-lycopersici viability was tested 3 weeks after MS application in the field. MS was significantly effective in reducing the $F$. oxysporum f. sp. radicislycopersici population by 77 to $100 \%$ after the first application, compared with nontreated plots. No significant difference was found in F. oxysporum f. sp. radicis-lycopersici mortality between first and second MS applications (Table 5). Vine collapse and plant death were observed in the nontreated plots 40 days after planting. Disease incidence in the nontreated plot was $98 \%$ after 60 days. A single MS application reduced disease incidence by $56 \%$ following first application. MS at the low rate was still effective following the second consecutive application: $61 \%$ diseased plants compared with the respective control (Table 5). No significant differences were found in disease incidence or fruit yield between the first and second crops. There was no significant difference in any of the parameters among MS treatments (300 and 600 liter ha ${ }^{-1}$ ).

\section{DISCUSSION}

Our study showed that AD of MS can be developed in commercial fields under regular agricultural practices. The results from the field studies pertaining to pathogen and disease control (and, in certain cases, also the effect on yield) corresponded with those from the studies carried out under controlled conditions.

TABLE 4. Effect of repeated applications of metam-sodium (MS) on incidence and severity of Verticillium wilt and on tuber yield in potato, assessed with various application histories (experiment 3$)^{\mathrm{v}}$

\begin{tabular}{lcccc}
\hline Treatment $^{\mathrm{w}}$ & Field $^{\mathrm{x}}$ & $\begin{array}{c}\text { Disease } \\
\text { incidence }(\%)\end{array}$ & $\begin{array}{c}\text { Disease severity } \\
(\text { scale 0 to 3) }\end{array}$ & $\begin{array}{c}\text { Total yield } \\
\left(\mathrm{kg} \mathrm{m}^{-2}\right)^{\mathrm{z}}\end{array}$ \\
\hline Nontreated (0) & I & $100.00 \mathrm{a}$ & $2.24 \mathrm{a}$ & $3.06 \mathrm{a}$ \\
MS (1 appl.) & I & $62.05 \mathrm{a}$ & $0.83 \mathrm{~b}$ & $2.68 \mathrm{a}$ \\
Nontreated (0) & II & $100.00 \mathrm{a}$ & $2.00 \mathrm{a}$ & $2.34 \mathrm{~b}$ \\
MS (2 appl.) & II & $55.25 \mathrm{a}$ & $0.78 \mathrm{a}$ & $3.23 \mathrm{a}$ \\
Nontreated (0) & III & $98.22 \mathrm{a}$ & $2.02 \mathrm{a}$ & $2.11 \mathrm{~b}$ \\
MS (3 appl.) & III & $90.63 \mathrm{a}$ & $1.41 \mathrm{a}$ & $2.76 \mathrm{a}$ \\
\hline
\end{tabular}

${ }^{\mathrm{v}}$ Different letters within each column, denote significant differences between nontreated and MS application for each field section separately according to $t$ test $(P \leq 0.05)$.

${ }^{w}$ Number of MS applications shown in parentheses.

${ }^{x}$ Field section I: MS was applied only once in 2004. Field section II: MS was applied twice, in 2003 and 2004. Field section III: MS was applied three times, in 2002, 2003, and 2004. All values refer to the 2004 crop.

y Disease severity was assessed by collecting stems of potato from each treatment. Stems were rated for wilt and discoloration on a scale of 0 to 3 , where $0=$ no disease symptoms and $3=$ dead plant with microsclerotia on the stem.

${ }^{\mathrm{z}}$ Potato tubers were collected and weighed 130 days after planting. 
Rapid dissipation of MITC, the active component of MS, in soil can lead to a reduction in the effectiveness of pathogen and disease control. Repeated applications of MS to different soils led to varied levels of AD of MITC.

The generation and dissipation of MITC following a single (first) application of MS varied among the different soils. The persistence of MITC in the soil is reflected in the product of $\mathrm{C}_{\text {MITC }}$ $\times \mathrm{T}$ and in the level of mortality of a test organism in the laboratory. These parameters are also aligned with disease control in the field and, therefore, they can serve as tools for assessing and predicting the effectiveness of MS fumigation in these soils (40). In the current study, repeated applications of MS to the three tested soils in the laboratory under controlled conditions resulted in a wide spectrum of MITC generation and dissipation rates (Fig. 1 ), and of $\mathrm{C}_{\text {MITC }} \times \mathrm{T}$ values and mortality levels of $F$. oxysporum $\mathrm{f}$. sp. radicis-lycopersici, used as a bioassay organism (Table 1). Our results on the AD of MITC corresponded with previous studies on the AD of MS in soils in the Netherlands (33) and Israel (7). The results obtained under laboratory conditions on dissipation (40) and AD (Fig. 1; Table 1) corresponded well with those obtained from soils treated under field conditions (Fig. 2). In the Di Primo et al. study (7), the effectiveness of MS after repeated applications was assessed using pathogen mortality, which was found to be reduced in 10 Israeli soils (including Beeri). Here, repeated applications of MS resulted in the rapid degradation of MITC in two of the three tested soils (Figs. 1 and 2 ), indicating that the phenomenon can be induced by repetitive application under both laboratory and field conditions but that its intensity depends on the origin of the soil tested.

There are a variety of studies that demonstrate the development of $\mathrm{AD}$ of pesticides in soil samples collected from fields and tested under controlled conditions, including herbicides $(4,23,25$, $32,39,48)$, nematicides $(18,24,35,36)$, insecticides $(37,38)$, and fungicides $(26,43,44)$. However, there are fewer studies dealing with the $\mathrm{AD}$ of pesticides in soil and the consequent pesticidal activity under field conditions $(15,27)$. This study presents evidence of reduced MS efficacy following repeated applications under field conditions, as reflected by the control of root diseases and, in certain cases, by yield loss, in parallel to AD development under controlled conditions.

The low effectiveness of MS to control disease found in certain cases (12) might be related to AD of this disinfestant. In our study (experiment 1), the effect of MS application on disease control

TABLE 5. Effect of repeated applications of metam-sodium (MS) on incidence of sudden wilt and on yield in melons (experiment 4)

\begin{tabular}{|c|c|c|c|c|}
\hline Treatment & $\begin{array}{l}\text { No. of } \\
\text { appl.w }\end{array}$ & $\begin{array}{l}\text { Mortality } \\
(\%)^{\mathrm{x}}\end{array}$ & $\begin{array}{c}\text { Disease } \\
\text { incidence }(\%)\end{array}$ & $\begin{array}{c}\text { Yield } \\
\left(\mathrm{kg} \mathrm{m}^{-2}\right)^{\mathrm{y}}\end{array}$ \\
\hline Nontreated & 0 & 0.00 & 98.50 & 0.83 \\
\hline MS (300 liter ha ${ }^{-1}$ ) & 1 & 100.00 & 43.48 & 1.92 \\
\hline MS (600 liter ha $\left.{ }^{-1}\right)$ & 1 & 100.00 & 36.23 & 1.73 \\
\hline Nontreated & 0 & 0.00 & 100.00 & 0.44 \\
\hline MS (300 liter ha $\left.{ }^{-1}\right)$ & 2 & 76.77 & 60.87 & 1.62 \\
\hline MS (600 liter ha-1) & 2 & 100.00 & 46.38 & 1.52 \\
\hline \multicolumn{5}{|l|}{$\operatorname{MSD}(P<0.05)^{\mathrm{z}}$} \\
\hline Treatment & $\ldots$ & 45.38 & 42.43 & 0.91 \\
\hline Year & $\ldots$ & ND & ND & ND \\
\hline
\end{tabular}

${ }^{w}$ Number of MS applications. Nontreated plots correspond to the respective MS treatments.

${ }^{x}$ Nylon net bags containing soil infested with chlamydospores of Fusarium oxysporum f. sp. radicis-lycopersici were buried in the field plot before MS application. The bags were retrieved 3 weeks later and mortality was calculated by comparison with propagule viability in nontreated soil.

y Melon fruits were collected and weighed 130 days after planting.

${ }^{\mathrm{z}}$ Mean significant difference (MSD) of main effects. Statistical analysis of the main effects shows a significant effect of treatment $(F=22.07, P \leq 0.0006$; $F=7.52, P \leq 0.0076 ; F=6.64, P \leq 0.0114$ ) on mortality, disease incidence, and yield, respectively. ND $=$ no significant differences were found between years $(P \geq 0.05)$. did not correspond to the effect on total yield of peanut pods as evaluated at harvest; however, the effectiveness of MS was reflected in pod quality (Table 2), which is very important from an economic point of view. Similarly, Frank et al. (9) found that MS application does not improve the total yield of peanut pods but does increase the percentage of healthy pods. Indeed, pathogens of peanut pods usually do not destroy the pods but, rather, lower the quality of the shell.

Our results (experiment 2) showed that, in 2002, following the first application, MS was significantly effective at controlling Verticillium wilt in potato (67\% reduction) but, after two and three consecutive applications, Verticillium disease reduction was only 18 and $8 \%$, respectively (Table 3). MS was effective in controlling Verticillium wilt in another experiment (Table 4), with a single or double MS application resulting in a reduction in disease incidence (by 38 and $45 \%$, respectively) compared with only $8 \%$ after a triple application. A similar trend was observed with respect to disease severity. There was no clear trend with respect to yield increase by MS, or any correlation between disease control and yield increase.

Repeated applications of MS were still effective at controlling sudden wilt disease of melon (experiment 4) in a soil in which MS dissipation is relatively slow (Fig. 1) (40). MS treatments reduced the final incidence of the disease by 47 to $58 \%$ relative to nontreated plots, with no significant difference between first and second MS application (Table 5) and yields that were similar in both years. There were no significant differences between the two MS dosages with respect to the three tested parameters. In other studies, a combination of soil solarization and fumigation with MS (6) or MS application alone (12) was significantly effective in controlling sudden wilt disease and in increasing fruit yield compared with nontreated plots.

In contrast to many reports on $\mathrm{AD}$ of various pesticides, only a few studies have looked at this phenomenon with soil fumigants such as MS. This soil fumigant is becoming one of the major alternatives to methyl bromide and, therefore, developing tools to manage its possible AD (e.g., by combining it with other biocides or disinfestation methods) (19) is greatly needed. In many cases, $\mathrm{AD}$ has been correlated with enhanced microbial degradation capacity $(1,23,25,39,48)$. This aspect is currently under investigation.

\section{ACKNOWLEDGMENTS}

We thank the field staff of the Beeri, Moshvei HaNegev corporation and Zohar Experimental Station for their valuable assistance in the field experiments; V. Zilberg, M. Beniches, J. Rivan, E. Klein, E. Zehavi, and O. Hieman, for their technical assistance; and Agan-Makktechim for providing the metam-sodium for all studies. This research was supported by grants No. 459-0354 from the Chief Scientist of the Israeli Ministry of Agriculture and Rural Development. Mention of a proprietary product does not constitute an endorsement or recommendation for use by the Israeli Ministry of Agriculture, nor does it imply the lack of efficacy of similar products not mentioned. Contribution 707/08 series from the Agricultural Research Organization, The Volcani Center, Bet Dagan, Israel.

\section{LITERATURE CITED}

1. Arbeli, Z., and Fuentes, C. L., 2007. Accelerated biodegradation of pesticides: An overview of the phenomenon, its basis and possible solutions; and a discussion on the tropical dimension. Crop Prot. 26:17331746.

2. Ausher, R., Katan, J., and Ovadia, S. 1975. An improved selective medium for the isolation of Verticillium dahliae. Phytoparasitica 3:133-137.

3. Austerweil, M., Gamliel, A., Di Primo, P., and Steiner, B. 2002. Elucidation of the behavior of fumigants in soil by solid microextraction (SPME) and gas liquid chromatography (GC). Proc. 10th IUPAC Congr. Chem. Crop Prot. Basel, Switzerland, Vol. 2:37.

4. Avidov, E., Aharonson, N., Katan, J., Rubin, B., and Yarden, O. 1985. Persistence of Terbutryn and atrazine in soil as affected by soil 
disinfestation and fungicides. Weed Sci. 33:457-461.

5. Boesten, J. J. T. I., van der Pas, L. J. T., Smelt, J. H., and Leistra, M. 1991. Transformation rate of methyl isothiocyanate and 1,3-dichloropropene in water-saturated sandy subsoils. Neth. J. Agric. Sci. 39:179190.

6. Cohen, R., Pivonia, S., Burger, Y., Edelstein, M., Gamliel, A., and Katan, J. 2000. Toward integrated manegment of Monosporascus wilt of melon in Israel. Plant Dis. 84:496-505.

7. Di Primo, P., Gamliel, A., Austerweil, M., Steiner, B., Beniches, M., Peretz-Alon, I., and Katan, J. 2003. Accelerated degradation of metamsodium and dazomet in soil: Characterization and consequences for pathogen control. Crop Prot. 22:635-646.

8. Eshel, D., Gamliel, A., Grinstein, A., and Katan, J. 1999. Evaluation of soil fumigants on soilborne fungal pathogens in a controlled-environment system and in soil. Crop Prot. 18:437-443.

9. Frank, Z. R., Ben-Yephet, Y., and Katan, J. 1986. Synergistic effect of metham and solarization in controlling delimited shell spots of peanut pods. Crop Prot. 5:199-202.

10. Gamliel, A., Grinstein, A., Peretz-Alon, I., Klein, L., Nachmias, A., Tsror, L., Livescu, L., and Katan, J. 1997. Reduced dosage of methyl bromide for controlling Verticillium wilt of potato in experimental and commercial plots. Plant Dis. 81:469-474.

11. Gamliel, A., and Katan, J. 1991. Involvement of fluorescent pseudomonads and other microorganisms in increased growth response of plants in solarized soils. Phytopathology 81:494-502.

12. Gamliel, A., Triky, S., Austerweil, M., Di Primo, P., Beniches, M., Steiner, B., Peretz-Alon, I., and Ucko, O. 2005. Combined soil fumigants: Synergistic performance and improved yield. Acta Hortic. 698:135-140.

13. Gan, J., Papiernik, S. K., Yates, S. R., and Jury, W. A. 1999. Temperature and moisture effects on fumigant degradation in soil. J. Environ. Qual. 28:1436-1441.

14. Gerstl, Z., Mingelgrin, U., and Yaron, B. 1977. Behavior of Vapam and methylisothiocyanate in soils. Soil. Sci. Soc. Am. J. 41:545-548.

15. Gray, R. A., and Joo, G. K. 1985. Reduction in weed control after repeat applications of thiocarbamate and other herbicides. Weed Sci. 33:698702.

16. Grinstein, A., Kritzman, G., Riven, Y., Peretz-Alon, I., and Bar, Z. 1997. Chemical and physical disinfection of peanut pods for improved seed quality. Crop Prot. 16:353-357.

17. Hollowell, J. E., Shew, B. B., Beute, M. K., and Abad, Z. G. 1998. Occurrence of pod rot pathogen in peanuts grown in North Carolina. Plant Dis. 82:1345-1349

18. Karpouzas, D. G., Karanasios, E., and Menkissoglu-Spiroudi, U. 2004. Enhanced microbial of cadusafos in soils from potato monoculture: Demonstration and characterization. Chemosphere 56:549-559.

19. Katan, J., and Aharonson, N. 1989. Accelerated degradation of pesticides. Pages 193-207. in: Toxic Organic Chemicals in Porous Media. Ecological Studies, 73. Z. Gerstl, Y. Chen, U. Mingelgrin, and B. Yaron, eds. Springer-Verlag, Berlin.

20. Kaufman, D. D., Katan, J., Edwards, D. F., and Jordan, E. D. 1985. Microbial adaptation and metabolism of pesticides. Pages 437-451 in: Agricultural Chemicals of the Future. J. L. Hilton, ed. Rowman \& Allanheld Press, NJ.

21. Knight, H. 1925. Factors affecting efficiency in fumigation with hydrocyanic acid. Hilgardia 1:35-56.

22. Krikun, J., and Frank, Z. R. 1982. Metham sodium applied by sprinkler irrigation to control pod rot and Verticillium wilt of peanut. Plant Dis. 66:128-130.

23. Krutz, L. J., Zablotowicz, R. M., Reddy, K. N., Koger, C. H., III, and Weaver, M. A. 2007. Enhanced degradation of atrazine under field conditions correlates with a loss of weed control in the glasshouse. Pest Manage. Sci. 63:23-31.

24. Moens, T., Araya, M., Swennen, R., and De Waele, D. 2004. Enhanced biodegradation of nematicides after repetitive applications and its effect on root and yield parameters in commercial banana plantations. Biol. Fertil. Soils. 39:407-414.

25. Piutti, S., Marchand, A. L., Lagacherie, B., Martin-Laurent, F., and Soulas G. 2002. Effect of cropping cycles and repeated herbicide applications on degradation of diclofop-mthyl, bentazone, diuron, isoproturon and pendimethalin in soil. Pest Manage. Sci. 58:303-312.
26. Potter, T. L., Strickland, T. C., Joo, H., and Culbreath, A. K. 2005 Accelerated soil dissipation of tebuconazole following multiple applications to peanuts. J. Environ. Qual. 34:1205-1213.

27. Rahman, A., and James, T. K. 1983. Decreased activity of EPTC + R25788 following repeated use in some New Zealand soils. Weed Sci. 31:783-789.

28. Rowe, R. C., and Powelson, M. L. 2002. Potato early dying: Management challenges in a changing production environment. Plant Dis. 86:11841193.

29. Ruso, L. O. 2006. Physical, chemical and environmental properties of selected chemical alternatives for the pre-plant use of methyl bromide as soil fumigant. Pest Manage. Sci. 62:99-113.

30. Saeed, I. A. M., Rouse, D. I., Harkin, J. M., and Smith, K. P. 1997. Effects of soil water content and soil temperature on efficacy of metam-sodium against Verticillium dahliae. Plant Dis. 81:773-776.

31. Schmitthenner, A. J. 1979. Pythium species: Isolation biology and identification. Pages 33-36 in: Advances in Turfgrass Pathology. Proc. Symp. Turfgrass Dis. P. O. Larsen and B. G. Jogner, eds. Harcourt Brace Jovanovich Publication, Duluth, MN.

32. Shaner, D. L., and Henry, W. B. 2007. Field history and dissipation of atrazine and metolachlor in Colorado. J. Environ. Qual. 36:128-134.

33. Smelt, J. H., Crum, S. J. H., and Teunissen, W. 1989. Accelerated transformation of the fumigant methyl isothiocyanate in soil after repeated application of metam-sodium. J. Environ. Sci. Health B24(5):437455 .

34. Smelt, J. H., and Leistra, M. 1974. Conversion of metham-sodium to methyl isothiocyanate and basic data on the behaviour of methyl isothiocyanate in soil. Pestic. Sci. 5:401-407.

35. Smelt, J. H., Teunissen, W., Crum, S. J. H., and Leistra, M. 1989. Accelerated 1,3-dichloropropene transformation in loamy soils. Neth. J. Agric. Sci. 37:173-183.

36. Smelt, J. H., van de Peppel Groen, A. E., van der Pas, L. J. T., and Dijksterhuis, A. 1996. Development and duration of accelerated degradation of nematicides in different soils. Soil Biol. Biochem. 12:17571765 .

37. Suett, D. L. 1986. Accelerated degradation of carbofuran in previously treated field soils in the United Kingdom. Crop Prot. 5:165-169.

38. Suett, D. L., and Walker, A. 1988. Accelerated degradation of soil-applied pesticides-implications for UK horticulture. Asp. Appl. Biol. 17:213-222.

39. Tal, A., Rubin, B., and Katan, J. 1989. Accelerated degradation of thiocarbamate herbicides in Israeli soils following repeated use of vernolate. Pestic. Sci. 25:343-353.

40. Triky-Dotan, S., Austerweil, M., Steiner, B., Peretz-Alon, Y., Katan, J., and Gamliel, A. 2007. Generation and dissipation of methyl isothiocyanate in soils following metam sodium fumigation: Impact on Verticillium control and potato yield. Plant Dis. 91:497-503.

41. Tsror, L., Shlevin, E., and Peretz-Alon, I. 2005. Efficacy of metam sodium for controlling Verticillium dahliae prior to potato production in sandy soils. Am. J. Potato Res. 82:419-423.

42. Verhagen, C., Lebbink, G., and Bloem, J. 1996. Enhanced biodegradation of the nematicides 1,3-dichloropropene and methyl isothiocyanate in a variety of soils. Soil Biol. Biochem. 28:1753-1756.

43. Walker, A. 1987. Further observations on the enhanced degradation of iprodione and vinclozolin in soil. Pestic. Sci. 21:219-231.

44. Walker, A., Brown, P. A., and Entwistle, A. R. 1986. Enhanced degradation of iprodione and vinclozolin in soil. Pestic. Sci. 17:183-193.

45. Wang, D., and Yates, S. R. 1999. Spatial and temporal distributions of 1,3dichloropene in soil under drip and shank application and implications for pest control efficacy using concentration-time index. Pestic. Sci. 55:154160 .

46. Warton, B., and Matthiessen, J. N. 2000. Enhanced biodegradation of metam sodium soil fumigant in Australia. Proc. BCPC Conf. Pests Dis. 2000 4C-4:377-380.

47. Warton, B., Matthiessen, J. N., and Roper, M. M. 2001. The soil organisms responsible for the enhanced biodegradation of metam sodium. Biol. Fertil. Soils. 34:264-269.

48. Zablotowicz, R. M., Krutz, L. J., Reddy, K. N., Weaver, M. A., Koger, C. H., and Locke, M. A. 2007. Rapid development of enhanced atrazine degradation in a dundee silt loam soil under continuous corn and in rotation with cotton. J. Agric. Food Chem. 55:852-859. 